(2) Open Access Full Text Article

REVIEW

\title{
Biomarkers for the differentiation of anemia and their clinical usefulness
}

This article was published in the following Dove Press journal:

Journal of Blood Medicine

19 March 2013

Number of times this article has been viewed

\author{
Christine A Northrop- \\ Clewes' \\ David I Thurnham² \\ 'Nutrition Consultant, \\ Cambridge, UK; ${ }^{2}$ Northern Ireland \\ Centre for Food and Health, School \\ of Biomedical Sciences, University of \\ Ulster, Coleraine, UK
}

\begin{abstract}
The World Health Organization defines anemia as the point at which the amount of hemoglobin in the circulation falls below World Health Organization cutoffs for specific age and sex groups. Anemia is a worldwide problem of complex etiology and is associated with many factors. The purpose of this review was to describe the biomarkers used to identify the nature of anemia in patients and in the community. The important biomarkers are the automated red cell counts, tests for nutritional deficiencies, hemoglobinopathies, and inflammation. Diseases are important potential initiators of anemia, but biomarkers of specific diseases are not included in this review, only the underlying feature common to all disease - namely, inflammation.

Keywords: iron deficiency, biological markers, blood cell count, inflammation, avitaminosis, hemoglobinopathies
\end{abstract}

\section{Introduction}

The World Health Organization (WHO) estimates that 1.62 billion people ( $95 \%$ confidence interval [CI]: $1.50,1.74$ billion), corresponding to $24.8 \%$ (95\% CI: 22.9 , 26.7) of the global population, are affected by anemia. ${ }^{1}$ However, although anemia affects all population groups in all countries of the world, certain groups are more vulnerable than others. The highest prevalence tends to be in preschool-age children (ie, those aged 6-59 months), women of reproductive age (ie, those aged 15-49 years), and pregnant women (Table 1). Data for lactating women do not seem to be available at the national level.

\section{Anemia}

Anemia is defined as a hemoglobin $(\mathrm{Hb})$ concentration below certain thresholds established for specified population groups living at sea level (Table 2). ${ }^{2} \mathrm{Hb}$ is the main component of erythrocytes or red blood cells (RBCs). Red cell synthesis takes place in the bone marrow and is under the control of erythropoietin produced by interstitial fibroblasts in the kidney. There are several intermediate stages in the development of the mature erythrocyte during which $\mathrm{Hb}$ is synthesized and the nucleus is catabolized. Limitations in the supply of several essential micronutrients can affect the production of new cells. Vitamins $\mathrm{B}_{6}$ (pyridoxine) ${ }^{3}$ and $\mathrm{B}_{2}$ (riboflavin) ${ }^{4,5}$ are needed for the synthesis of the protein globin and iron has to be incorporated into the final $\mathrm{Hb}$ molecule. ${ }^{6}$ Restrictions in the supply of these nutrients will produce small red cells (microcytosis) with low $\mathrm{Hb}$ concentration (hypochromia). In addition, zinc may be substituted in the absence of iron, giving rise to zinc protoporphyrin in the red cell. ${ }^{7}$ Limitations in the supply of folate and vitamin $B_{12}$ (cyanocobalamin) reduce the number of red cells
Correspondence: Christine A NorthropClewes

46 High Street, Little Wilbraham, Cambridge CB2I 5JY, UK

Email christinaclewes@btinternet.com submit your manuscript $\mid$ www.dovepress.com

Dovepress

http://dx.doi.org/10.2147/]BM.S29212 
Table I Anemia prevalence in preschool-age children (pre-SAC) ${ }^{\mathrm{a}}$ and women of reproductive age (pregnant and nonpregnant women) by World Health Organization (WHO) region ${ }^{\mathrm{b}}$

\begin{tabular}{llll}
\hline WHO region & \multicolumn{2}{l}{ Prevalence [\% $(95 \% \mathrm{CI})]$} \\
\cline { 2 - 4 } & Pre-SAC & $\begin{array}{l}\text { Pregnant } \\
\text { women }\end{array}$ & $\begin{array}{l}\text { Nonpregnant } \\
\text { women }\end{array}$ \\
\hline Africa & $67.6(64.3,7 I .0)$ & $57 . I(52.8,61.3)$ & $47.5(43.3,5 I .6)$ \\
Americas & $29.3(26.8,31.9)$ & $24 . I(17.3,30.8)$ & $17.8(I 2.9,22.7)$ \\
Southeast Asia & $65.5(61.0,70.0)$ & $48.2(43.9,52.5)$ & $45.7(41.9,49.4)$ \\
Europe & $21.7(15.4,28.0)$ & $25.1(18.6,31.6)$ & $19.0(14.7,23.3)$ \\
Eastern & $46.7(42.2,51.2)$ & $44.2(38.2,50.3)$ & $32.4(29.2,35.6)$ \\
Mediterranean & & & \\
Western Pacific & $23.1(21.9,24.4)$ & $30.7(28.8,32.7)$ & $21.5(20.8,22.2)$ \\
Global & $47.4(45.7,49.1)$ & $4 I .8(39.9,43.8)$ & $30.2(28.7,31.6)$ \\
\hline
\end{tabular}

Notes: ${ }^{P}$ Pre-SAC are those aged 6-59 months; ${ }^{b}$ data obtained from the WHO report Worldwide Prevalence of Anaemia 1993-2005: WHO Global Database on Anaemia.'

Abbreviation: $\mathrm{Cl}$, confidence interval.

produced, so cells can be larger than normal (macrocytosis) and this may or may not be accompanied by hypochromia. ${ }^{8}$ Where the rate of red cell production is higher than normal, a further feature may appear in some red cells - namely, remnants of ribosomes and rough endoplasmic reticulum and the cells are then called reticulocytes. ${ }^{7}$ The presence of reticulocytes is a feature of the hemolytic anemias. However, as micronutrient deficiencies rarely occur singly, the effects on the morphology of red cells during production can be mixed, producing a wide distribution of cell types.

Anemia, therefore, is an indicator of both poor nutrition and poor health resulting in increased risks of maternal and child mortality. $\mathrm{Hb}$ is transported in the circulation within the erythrocytes or RBCs, where its principal function is to carry oxygen to body tissues. The requirements for oxygen are influenced by environmental factors such as altitude and smoking and physiological factors such as gestation, and the body can change $\mathrm{Hb}$ concentrations and/or blood volumes to accommodate the need for oxygen. For statistical purposes, correction factors can adjust $\mathrm{Hb}$ concentrations to remove

Table 2 World Health Organization hemoglobin concentration thresholds used to define anemia at sea level ${ }^{2}$

\begin{tabular}{ll}
\hline Population group & Hemoglobin cutoff $(\mathrm{g} / \mathrm{L})$ \\
\hline Children & \\
Aged $0.50-4.99$ years & 110 \\
Aged 5.00-11.99 years & 115 \\
Aged $12.00-14.99$ years & 120 \\
Nonpregnant women & 120 \\
Pregnant women & 110 \\
Men & 130 \\
\hline
\end{tabular}

Note: Hemoglobin cut-offs are adjusted upwards to compensate for altitude and smoking. In pregnant women, hemoglobin is adjusted variably according to the stage of pregnancy. ${ }^{2}$ these influences. ${ }^{2}$ The prevalence of subjects with $\mathrm{Hb}$ concentrations below the defined thresholds (Table 2) is used to estimate the level of the public health problem within a country or region (Table 3). Infants younger than 6 months were excluded from the WHO estimates.

Although anemia is often the result of a complex interaction of a number of factors, the most significant contributor has always been thought to be iron deficiency. In the literature, statements such as "at least half the anemia is due to nutritional iron deficiency" and "up to a prevalence of $40 \%$ iron-deficiency anemia, iron deficiency will be about 2.5 times that of anemia"' have been widely reported. However, it is evident that there are considerable variations in both of these ratios depending on the age and sex of the people being studied, the region of the world in which they live, and the prevalence rates of other causes of anemia. Table 4 illustrates the major factors that contribute to anemia. ${ }^{7}$

Although diseases feature prominently in Table 4 - notably, malaria, human immunodeficiency virus, and helminth infections such as hookworm - it is not the purpose of this review to describe biomarkers for different diseases. Diseases will be dealt with by physicians as determined by the clinical need of their patients or, in the community, by distribution of prophylactic measures such as bed nets, albendazole, and so forth. However, many diseases exert their effects on the hemopoietic system through the inflammatory response. ${ }^{10}$ This produces the type of anemia known as "anemia of chronic inflammation" (ACI) and because of the widespread distribution of endemic disease in much of the developing world, ACI may be an important etiological component of anemia globally. Therefore, inflammation biomarkers will be included in this review, as they indicate the disease exposure in the individual and the community.

Measuring the blood $\mathrm{Hb}$ concentration is the most reliable indicator of anemia at the population level and it is used in national demographic health surveys and by national governments surveying populations before making new policy for nutritional interventions such as the distribution of supplements or the fortification of staple foods. Measuring $\mathrm{Hb}$

Table 3 World Health Organization classifications of anemia that define the extent of the public health problem within a country or region ${ }^{2}$

\begin{tabular}{ll}
\hline Prevalence of anemia (\%) & Category of public health significance \\
\hline$\leq 4.9$ & No public health problem \\
$\geq 5.0-19.9$ & Mild public health problem \\
$\geq 20.0-39.9$ & Moderate public health problem \\
$\geq 40.0$ & Severe public health problem \\
\hline
\end{tabular}

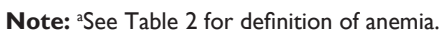


Table 4 Major factors contributing to anemia and principal biomarkers for interpretation

\begin{tabular}{|c|c|}
\hline Cause & Biomarkers \\
\hline Iron deficiency & $\begin{array}{l}\text { Ferritin, soluble transferrin } \\
\text { receptors, serum iron, red cell } \\
\text { morphology, bone marrow }\end{array}$ \\
\hline $\begin{array}{l}\text { Other nutritional deficiencies } \\
\text { such as folate, vitamin } B_{12} \text {, vitamin } B_{6} \text {, } \\
\text { riboflavin, and vitamin } A\end{array}$ & $\begin{array}{l}\text { Specific nutritional indicators, } \\
\text { dietary intake data, red cell } \\
\text { morphology }\end{array}$ \\
\hline Malaria & $\begin{array}{l}\text { Parasite antigen tests, thick and } \\
\text { thin blood films for parasite counts }\end{array}$ \\
\hline $\begin{array}{l}\text { Helminth infections, especially } \\
\text { hookworm and schistosomiasis }\end{array}$ & $\begin{array}{l}\text { Stool and/or urine egg counts, } \\
\text { immunological tests }\end{array}$ \\
\hline $\begin{array}{l}\text { Chronic infections (eg, HIV/AIDS, } \\
\text { tuberculosis, cancer, rheumatoid } \\
\text { arthritis) }\end{array}$ & $\begin{array}{l}\text { Specific clinical tests to identify } \\
\text { pathogens or pathological state }\end{array}$ \\
\hline $\begin{array}{l}\text { Hemoglobinopathies (eg, sickle-cell } \\
\text { disease and thalassemia) }\end{array}$ & $\begin{array}{l}\text { Genetic screening } \\
\text { electrophoresis }\end{array}$ \\
\hline Inflammation & $\begin{array}{l}\text { Acute-phase proteins, white } \\
\text { blood cell count }\end{array}$ \\
\hline $\begin{array}{l}\text { Physiological blood losses in women } \\
\text { associated with pregnancy } \\
\text { and menstruation }\end{array}$ & Medical diagnoses \\
\hline Gastric and intestinal diseases & Fecal blood \\
\hline
\end{tabular}

Abbreviations: HIV, human immunodeficiency virus; AIDS, acquired immune deficiency syndrome.

is easy and relatively cheap. In many surveys the portable $\mathrm{HemoCue}^{\circledR}$ (Hemocue AB, Ängelholm, Sweden) device is used to get an instant reading of the concentration; the result can be given to the household straight away, and, if necessary, action can be taken if concentrations are low (eg, referral to clinic for a course of iron tablets, test for malaria). In a clinical setting or in continuous national cross-sectional surveys (eg, the UK National Diet and Nutrition Survey [NDNS]), $\mathrm{Hb}$ is usually measured using automated red cell-counting equipment. However, it must always be remembered that a low $\mathrm{Hb}$ concentration is not necessarily a measure of iron deficiency and that more detailed investigations are needed to determine the cause of the anemia.

\section{Biomarkers to differentiate anemias Red cell-counting techniques to differentiate anemias}

Measurement of erythrocytes and reticulocyte numbers using automated flow cytometers is useful for evaluating anemia in both routine and clinically complex settings, particularly for the high degree of precision attainable. Automated flow cytometers provide information on a number of red cell parameters (Table 5). However, access to complex equipment is more problematic in developing countries, where red cell-counting chambers, stained blood films, photometers, and centrifuges may be the only equipment available. In the absence of automated cell counters, different hematological approaches may be needed; however, these approaches will not be discussed here. ${ }^{6}$

\section{Red cell count}

The normal number of red cells per cubic microliter of blood is 5 million, with slightly more in men (4.5-6.5 million) than in women (3.9-5.6 million). ${ }^{6}$ The introduction of equipment with automated counting meant that all the indices described in Table 5 are now far more accurate and useful than when only the manual techniques were available.

\section{Mean corpuscular volume}

The mean corpuscular volume (MCV) and the mean corpuscular $\mathrm{Hb}$ concentration (MCHC) provide identical information and are interchangeable in identifying a microcytic anemia. MCV has been used most widely and is a measure of the average size of the RBCs. A MCV below the reference value is usually an indication of iron deficiency (Table 5). However, low values are not specific to iron deficiency and can be found in those with thalassemia and in about 50\% of people with anemia due to inflammation. Conversely, if MCV values are above the reference value, they indicate macrocytic anemia caused by, for example, folate or $\mathrm{B}_{12}$ deficiency and also alcohol abuse, liver disease, and hypothyroidism.

\section{Reticulocytes}

Reticulocytes are young, anucleate erythrocytes, which are released from bone marrow into the blood in increased numbers as a response to anemia caused by hemolysis (destruction) or loss (hemorrhage) of erythrocytes. Detection and identification of immature anucleate RBCs verifies whether the bone marrow is responding to the anemia by increasing $\mathrm{RBC}$ production in a regenerative response. The reticulocytes are evaluated by the presence of ribonucleic acid (RNA) in the cytoplasm of immature erythrocytes. The more immature the cell, the more RNA it will contain. If the anemia is regenerative, there will be an above-normal number of reticulocytes and polychromasia (variation in the $\mathrm{Hb}$ content of erythrocytes) in peripheral blood. In contrast, mature $\mathrm{RBCs}$, which are no longer synthesizing $\mathrm{Hb}$, contain very small amounts of or no RNA.

Because the life span of reticulocytes is longer in anemic subjects, the reticulocyte proliferation index is normally calculated (Table 5). Low values indicate a low production of red cells possibly due to nutrient deficiency, whereas high 
Table 5 Biomarkers of anemia from red cell morphology

\begin{tabular}{|c|c|c|c|}
\hline Biomarker & Reference value & Calculation or measurement & Interpretation \\
\hline \multirow[t]{2}{*}{ Total RBC count $\times 10^{12} / \mathrm{L}$} & Men: $4.2-5.9$ & NR & Low: anemia \\
\hline & Women: $3.6-5.3$ & & High: dehydration, high altitude, smoking \\
\hline \multirow[t]{2}{*}{ Hematocrit (PCV) ${ }^{a}$} & Men: 0.45 L/L (-2SD 0.39) & Proportion of RBCs as percentage & Values $<0.39 \mathrm{~L} / \mathrm{L}$ in men and $<0.34 \mathrm{~L} / \mathrm{L}$ \\
\hline & Women: 0.4 L/L (-2SD 0.34) & of total blood volume & in women indicate anemia \\
\hline \multirow[t]{2}{*}{ MCV } & $83-101 \mathrm{fL}$ & $10 \times \mathrm{PCV}(\%) / \mathrm{RBC}$ count $\left(10^{6} / \mu \mathrm{L}\right)$ & Microcytic: $<83 \mathrm{fL}$ indicates iron deficiency \\
\hline & & & $\begin{array}{l}\text { Macrocytic: }>101 \mathrm{fL} \text { suggests folate or } \\
\text { vitamin } B_{12} \text { deficiency }\end{array}$ \\
\hline \multirow[t]{2}{*}{$\mathrm{RC}$} & $\sim 0.5 \%-1 \%$ of RBCs in peripheral & Fluorescent dye marks cells with & Higher values are due to increased production \\
\hline & blood & RNA to distinguish from RBCs & $\begin{array}{l}\text { of RBCs in response to hemolysis or loss } \\
\text { of } R B C s \text { - regenerative anemia }\end{array}$ \\
\hline \multirow[t]{2}{*}{$\mathrm{RP}^{62}$} & $\mid \%-2 \%$ & $\mathrm{RC} \times\left(\mathrm{Hb}_{\text {obs }} / \mathrm{Hb}_{\text {normal }}\right) \times 0.5$ & $<1 \%$ indicates low production of new RBCs \\
\hline & & & $>2 \%$ indicates increased production of new RBCs \\
\hline \multirow[t]{2}{*}{ RDW } & $11 \%-15 \%$ & SD of MCV as percentage & $>15 \%$ indicates iron-deficiency anemia or \\
\hline & & of mean MCV & anemias of mixed origin \\
\hline \multirow[t]{2}{*}{$\mathrm{MCHC}$} & $4.9-5.5 \mathrm{mmol} / \mathrm{L}$ or as mass fraction & Mass fraction $\left(\mathrm{m}_{\mathrm{Hb}} / \mathrm{m}_{\mathrm{RBC}}\right)$ & Low: $<4.9 \mathrm{mmol} / \mathrm{L}$ indicates iron deficiency \\
\hline & $32-36 \mathrm{~g} / \mathrm{dL}$ or percentage & & High: macrocytic anemia \\
\hline
\end{tabular}

Note: Hematocrit cut-offs are adjusted upwards to compensate for increases in hemoglobin caused by altitude and smoking and adjusted variably according to the specific stage of pregnancy. ${ }^{2}$

Abbreviations: RBC, red blood cell; NR, not relevant; PCV, packed cell volume; 2SD, two standard deviations; MCV, mean corpuscular volume; RC, reticulocyte count; obs, observed; RNA, ribonucleic acid; RPI, reticulocyte proliferation index; Hb, hemoglobin; RDW, red cell distribution width; SD, standard deviation; MCHC, mean corpuscular hemoglobin concentration.

values indicate a high production of reticulocytes to replace lost blood and healthy hematopoiesis.

\section{Hematocrit or packed cell volume}

The hematocrit is the proportion of the blood volume occupied by RBCs and is determined by cell number and size. Concentrations below the reference range may indicate abnormal cell development. The normal hematocrit range used in a typical clinical setting is $0.4-0.5 \mathrm{~L} / \mathrm{L}$ for men and $0.36-0.46 \mathrm{~L} / \mathrm{L}$ for women. ${ }^{11}$ The WHO definition of a hematocrit for men aged $18-44.99$ years is $0.445 \mathrm{~L} / \mathrm{L}$ (minus two standard deviations: $0.39 \mathrm{~L} / \mathrm{L}$ ); the definition for women of a similar age is $0.4 \mathrm{~L} / \mathrm{L}$ (minus two standard deviations: $0.34 \mathrm{~L} / \mathrm{L}){ }^{2}{ }^{2}$ For international comparisons and statistical analyses, hematocrit is adjusted upward for gestation and downward for altitude and in smokers. ${ }^{2}$

\section{Red cell distribution width}

Red cell distribution width (RDW) is a measure of the variation of RBC width; the normal reference range is $11 \%-15 \%$ (Table 5). Usually RBCs are a standard size of about $6-8 \mu \mathrm{m}$, but certain disorders cause a significant variation in cell size. Higher RDW values indicate greater variation in size. If anemia is observed, RDW test results are often used together with MCV results to determine the possible causes of the anemia. ${ }^{12}$ The measure of RDW is mainly used to differentiate an anemia of mixed causes from an anemia of a single cause. Vitamin $B_{12}$ deficiency alone produces a macrocytic anemia with a normal RDW, while iron-deficiency anemia initially presents with a varied size distribution of RBCs, which show an increased RDW. In the case of a mixed iron and $\mathrm{B}_{12}$ and/or folate deficiency, there will be a mix of both large and small cells, causing the RDW to be elevated.

\section{$\mathrm{MCHC}$}

$\mathrm{MCHC}$ is a measure of the concentration of $\mathrm{Hb}$ in a given volume of packed RBCs. MCHC is a useful index because it incorporates red cell number, size, and $\mathrm{Hb}$ content. It is calculated by dividing the $\mathrm{Hb}$ concentration by the hematocrit, assuming a RBC concentration of $1 \mathrm{~g} / \mathrm{mL}$ and negligible $\mathrm{Hb}$ in plasma (Table 5). Low values indicate hypochromia and impaired synthesis of $\mathrm{Hb}$, while high values suggest folate or vitamin $\mathrm{B}_{12}$ deficiency.

\section{$\mathrm{Hb}$}

$\mathrm{Hb}$ is measured as a part of the automated red cell count using the cyanomethemoglobin method. Cells are lysed using Drabkin's solution to release the $\mathrm{Hb}$ into the fluid and convert it to cyanomethemoglobin, which is measured at $525 \mathrm{~nm}$.

\section{White cell count (leucocytes)}

The normal total white cell count varies from about 4000 to 10,000 per microliter with an average of 6000 per microliter. An increase in the total number of leucocytes to $15,000-25,000$ per microliter is termed a leucocytosis. The commonest cause of a polymorphonuclear leucocytosis is bacterial or generalized infection or tissue destruction by burns or surgery. ${ }^{6}$ Thus, a leucocytosis may indicate subclinical inflammation and may 
influence the interpretation of serum ferritin concentrations (see "Inflammation and anemia" section later in this review).

\section{Measurements of iron status}

\section{Iron deficiency}

Iron deficiency is a state in which there is insufficient iron to maintain the normal physiological function of tissues such as the blood, brain, and muscles.

Serum ferritin is the most useful biomarker to measure iron status, and concentrations $<12 \mu \mathrm{g} / \mathrm{L}$ for children younger than 5 years of age and $<15 \mu \mathrm{g} / \mathrm{L}$ for those 5 years and older are an indication of low iron stores in the body and a high risk of iron deficiency. Low iron stores in combination with anemia, as defined in Table 2, is termed iron-deficiency anemia. Iron-deficiency anemia is the final clinical stage of iron deficiency. Iron deficiency in the absence of anemia suggests that dietary iron intake is sufficient for metabolic requirements but insufficient to accumulate any stores. ${ }^{2}$

Unfortunately, in the presence of inflammation the concentration of ferritin is usually increased, even if iron stores are low; hence, it can be difficult to interpret the true concentration of ferritin in situations where exposure to inflammation is common. ${ }^{13}$ If the major causes of the inflammation are seasonal, and a national survey is needed, measurements should be performed in the season of lowest transmission or the concentration of ferritin can be adjusted for the influence of inflammation if the concentrations of serum C-reactive protein (CRP) and alpha-1-acid glycoprotein (AGP) are measured (see "Inflammation and anemia" section). ${ }^{13,14}$

\section{Serum iron, total iron-binding capacity, and transferrin saturation}

Serum iron, total iron-binding capacity (TIBC), and calculated transferrin saturation tests are used to screen for and monitor conditions of iron deficiency and iron overload. Mean concentrations of serum iron, which is transported by transferrin, are approximately 16-18 $\mu \mathrm{mol} / \mathrm{L}$ (95\% CI: 9, 26). Most people exhibit a morning peak and an evening nadir, and a consistent time of blood collection is recommended. ${ }^{15}$ High serum iron values can indicate hemolysis or iron overload but iron concentrations can be markedly $(>50 \%)$ and rapidly ( 24 hours) depressed by inflammation. ${ }^{16}$

The major source of iron for transferrin is the reticuloendothelial system, with some from hepatocytes and the intestine. Transferrin saturation also exhibits a daily fluctuation similar to that of serum iron, with a mean morning saturation of $35 \%$ and a normal range of $20 \%-50 \%$. Transferrin saturation can fall to $5 \%$ in iron deficiency and $15 \%$ in infection, and it can rise to
$80 \%$ in ineffective erythropoiesis (red cell maturation defect such as thalassemia) or $100 \%$ in idiopathic hemochromatosis (iron overload). In hemolytic anemia with effective erythropoiesis, transferrin saturation is slightly raised over normal to $45 \%$. Effective erythropoiesis can also be assessed using the reticulocyte proliferation index (Table 5). A saturation of $<16 \%$ is inadequate to meet basal erythropoietic needs. ${ }^{17}$

The total transferrin concentration in blood is usually expressed as the maximum iron-binding capacity of the plasma - namely, TIBC - and the normal concentration is $60 \mu \mathrm{mol} / \mathrm{L}$ (95\% CI: 45, 70). At birth, TIBC is $\sim 42 \mu \mathrm{mol} / \mathrm{L}$ and progressively rises through infancy to reach adult values at the age of 2 years. There is no difference between males and females at any age, but concentrations decline in older age groups. TIBC is higher in iron deficiency but lower in infection, hemolytic anemias, hemochromatosis, and undernutrition. During pregnancy, TIBC rises to 72 and $90 \mu \mathrm{mol} / \mathrm{L}$ at the fifth and eighth months, respectively. ${ }^{17}$

The generally high amount of unbound binding capacity on transferrin in normal subjects is believed to provide protection against unbound or "free" iron in the blood. ${ }^{17,18}$ In healthy subjects the unbound iron-binding capacity is around 65\%, and this can increase to $85 \%$ during infection. However, transferrin is a negative acute-phase protein (APP) and TIBC can fall to $40 \mu \mathrm{mol} / \mathrm{L}$ during infection, although the lower transferrin saturation (15\%) ensures the proportion of unbound ironbinding capacity is only slightly less than in healthy subjects ( $\sim 55 \%$ ) even though binding capacity is reduced.

\section{Storage iron}

Storage iron is the pool of iron in the body that is not being used by tissues. Healthy children and adults (apart from infants aged 6-11 months and pregnant women) usually have some iron stores to act as a buffer against iron deficiency during periods when dietary iron may be temporarily insufficient. ${ }^{7}$ Methods to express the amount of stored iron are based on the log ratio of serum soluble transferrin receptor (sTfR) to serum ferritin concentrations. ${ }^{19}$ The amount of body iron based on body weight can be calculated using the following equation, where sTfR is measured in milligrams per liter and ferritin is measured in micrograms per liter: ${ }^{19,20}$

$$
\begin{aligned}
\text { Body iron }(\mathrm{mg} / \mathrm{kg})= & -\left[\log _{10}(\mathrm{sTfR} \times 1000 /\right. \\
& \text { ferritin })-2.8229] / 0.1207
\end{aligned}
$$

\section{Iron depletion}

Iron depletion is the state in which storage iron is absent or nearly absent but the tissues that need iron are able to 
maintain normal physiological functions - that is, iron intake may be just sufficient to cover requirements. Evidence from animals fed on iron-deficient diets indicates that iron deficiency becomes detectable at about the same time in the blood, brain, and tissue enzyme systems, ${ }^{21}$ and low serum ferritin concentrations indicate when there is a high risk of impairing these functions.

It is possible for a functional iron deficiency to develop even when iron stores are present, if the normal physiological systems for transporting iron to target tissues or mobilizing iron from storage are impaired. This occurs most commonly because inflammatory cytokines released during infection under the influence of hepcidin prevent the normal transport of iron. ${ }^{22}$ Neither iron supplementation nor iron fortification have any benefit in such circumstances, as iron absorption is inhibited. ${ }^{23}$ Deficiencies of other nutrients such as vitamin A may also cause a functional iron deficiency even when iron stores are adequate, as these deficiencies can increase the risk and prevalence of disease. ${ }^{24}$

\section{Zinc protoporphyrin}

The presence of zinc protoporphyrin (ZPP) in blood reflects a shortage of iron in the last stages of making $\mathrm{Hb}$ so that zinc is inserted into the protoporphyrin molecule in the place of iron. ZPP can be detected in RBCs by fluorometry and is a measure of the severity of iron deficiency. ${ }^{7}$ For national surveys, a portable hematofluorometer is available (Aviv Biomedical, Inc, Lakewood, NJ, USA). The cutoff is a ZPP concentration of $>61 \mu \mathrm{mol} / \mathrm{mol}$ heme. ${ }^{2}$

\section{Serum sTfRs}

Serum sTfR concentrations are derived mostly from developing RBCs and so they reflect the intensity of erythropoiesis and the demand for iron; the concentration rises in iron-deficiency anemia and it is a marker of the severity of iron insufficiency, but only when iron stores have been exhausted, provided that there are no other causes of abnormal erythropoiesis. ${ }^{7}$ The concentration of sTfR is also increased in hemolytic anemia, thalassemia, and $\mathrm{Hb} \mathrm{E}$ (see Table 6 and later section "Hemoglobinopathies associated with anemia").

Although an international reference standard for STfR has been produced, ${ }^{25}$ there is still no reference range of concentrations. Skikne et $\mathrm{al}^{20}$ reported the mean sTfR concentration in normal subjects was $5.6 \mathrm{mg} / \mathrm{L}$ with a range of $2.8-8.5 \mathrm{mg} / \mathrm{L}$ (plus or minus two standard deviations) and a commercial kit produced in the United States (human transferrin receptor catalogue number TFC-94-CE; Ramco Laboratories, Inc, Stafford, TX, USA) suggests a normal range of $2.9-8.3 \mathrm{mg} / \mathrm{L}$, which has been used in many national surveys. ${ }^{26}$ In healthy adults, sTfR concentrations did not differ by sex or age between the ages of 18 and 80 years, but black subjects had significantly higher concentrations than nonblack (Caucasian, Hispanic, and Asian) subjects, and black and nonblack subjects living at high altitude had higher concentrations than those living closer to sea level. ${ }^{27}$ There is also evidence that sTfR concentrations are higher in infants (mean $7.8 \mathrm{mg} / \mathrm{L}$; 95\% CI: $4.5,11.1)$ than in prepubertal boys $(7.0 \mathrm{mg} / \mathrm{L} ; 95 \% \mathrm{CI}: 4.7$, $9.2)$, and higher in prepubertal boys than in men $(5.8 \mathrm{mg} / \mathrm{L}$; $95 \%$ CI: $3.1,8.5) .{ }^{28}$ The same authors also reported that lower serum ferritin and iron concentrations, even within the normal physiologic range, were associated with high sTfR concentrations and that the lower the serum ferritin concentrations, the higher the sTfR concentrations. ${ }^{28}$

\section{Disease and $\mathrm{ACl}$}

The distinction between iron-deficiency anemia and the anemia that accompanies inflammation is difficult to identify because indicators such as ferritin are influenced by the acute-phase response. Serum sTfR is not an APP, and concentrations remain in the normal range in ACI, but sTfR concentrations may be slightly elevated $(9 \mathrm{mg} / \mathrm{L})$ in nonanemic iron deficiency (ie, low ferritin concentrations) and more elevated in iron-deficiency anemia $(25 \mathrm{mg} / \mathrm{L}$; ie, low ferritin and low $\mathrm{Hb}$ ). Because sTfR concentrations barely change in ACI but are very much increased in iron-deficiency anemia, sTfR distinguishes between these anemias (Table 7). ${ }^{22,29}$

Table 6 Mean hematological variables for normal hemoglobin $(\mathrm{Hb})$ and four major $\mathrm{Hb}$ variants in Cambodian children aged 24-59 months

\begin{tabular}{llllll}
\hline Variable & HbAA & HbAE & $\begin{array}{l}\alpha \text {-thalassemia } \\
\text { trait }\end{array}$ & $\begin{array}{l}\text { Hb E trait and } \\
\alpha \text {-thalassemia trait }\end{array}$ \\
\hline Children $(\mathrm{n})$ & 531 & 325 & 204 & 122 & 77 \\
$\mathrm{Hb}(\mathrm{g} / \mathrm{L})$ & 114 & $110^{\mathrm{a}}$ & $111^{\mathrm{a}}$ & $108^{\mathrm{a}}$ & $98^{\mathrm{a}}$ \\
$\mathrm{sTfR}(\mathrm{mg} / \mathrm{L})$ & 7.1 & $7.4^{\mathrm{a}}$ & $7.5^{\mathrm{a}}$ & $7.5^{\mathrm{a}}$ & $9.6^{\mathrm{a}}$ \\
Ferritin $(\mu \mathrm{g} / \mathrm{L})^{\mathrm{b}}$ & 31.6 & 32.5 & 30.4 & 30.1 & 33.7 \\
\hline
\end{tabular}

Notes: Adapted with permission from George J, Yiannakis M, Main B, et al. Genetic hemoglobin disorders, infection, and deficiencies of iron and vitamin A determine anemia in young Cambodian children. J Nutr. 2012;142(4):78I-787.42 @ 2012 American Society for Nutrition. ${ }^{\mathrm{a} D i f f e r e n t}$ from concentration in HbAA group ( $\left.P<0.05\right)$; ${ }^{b}$ alues for ferritin were corrected for subclinical inflammation by methods in Thurnham et al. ${ }^{13}$

Abbreviations: HbAA, normal hemoglobin; HbAE, hemoglobin $E$ trait; $\alpha$, alpha; sTfR, soluble transferrin receptor; HbEE, homozygous hemoglobin $E$. 
Table 7 Changes in serum concentrations of markers of iron status in iron-deficiency anemia (IDA), anemia of chronic inflammation $(\mathrm{ACl})$, and the combination of both ${ }^{\mathrm{a}}$

\begin{tabular}{llll}
\hline Biomarkers & IDA & ACI & IDA + ACI \\
\hline Hemoglobin & $\downarrow$ & $\downarrow$ & $\downarrow$ \\
Serum iron & $\downarrow$ & $\downarrow$ & $\downarrow$ \\
Ferritin & $\downarrow$ & $\mathrm{NC}-\uparrow$ & $\uparrow$ \\
Soluble transferrin & $\uparrow$ & $\mathrm{NC}$ & $\mathrm{NC}-\uparrow$ \\
receptors (sTfR) & & & \\
Ratio sTfR/log ferritin & $\uparrow \uparrow($ ratio $>2)$ & $\mathrm{NC}($ ratio $<1)$ & $\uparrow($ ratio $>2)$ \\
Transferrin $^{\mathrm{b}}$ & $\uparrow$ & $\downarrow-\mathrm{NC}$ & $\downarrow-\mathrm{NC}$ \\
Inflammatory $_{\text {cytokines }}$ & $\mathrm{NC}$ & $\uparrow$ & $\uparrow$ \\
\hline
\end{tabular}

Notes: a Arrows indicate the direction of a change; btransferrin is a negative acutephase protein, so concentrations fall slightly during inflammation; inflammatory cytokines include hepcidin, interleukin 6, and others.

Adapted with permission from Northrop-Clewes CA. Interpreting indicators of iron status during an acute phase response: lessons from malaria and human immunodeficiency virus. Ann Clin Biochem. 2008;45(Pt I):18-32, ${ }^{22}$ and Beguin Y Soluble transferrin receptor for the evaluation of erythropoiesis and iron status. Clin Chim Acta. 2003;329(I-2):9-22. ${ }^{29}$

Abbreviations: NC, no change; NC-s $\uparrow$, no change or slight increase; NC- $\downarrow$, no change or slight decrease; $\uparrow \uparrow$, very strong increase.

The production of inflammatory cytokines, such as tumor necrosis factor-alpha and hepcidin in infection can suppress both hematopoiesis, by inhibition of erythropoietin production, and erythropoiesis, by inhibition of iron mobilization. ${ }^{23,30}$ For example, in a chronic inflammatory condition such as rheumatoid arthritis, serum sTfR concentrations can remain within the normal range even when iron stores are depleted because of the aforementioned effects. ${ }^{31}$ Therefore, the relationship between iron deficiency and STfR concentrations in ACI is usually inversely dependent on the degree of inflammation since inflammation will depress erythropoietin production and bone marrow activity. ${ }^{29,32}$

\section{Other nutritional deficiencies associated with anemia \\ Folates}

Folates are a group of water-soluble vitamins that are important in the transfer of one-carbon units in amino acid interconversions and which are therefore essential for protein synthesis and in hematopoiesis. Serum folate concentrations start to fall after about 3 weeks of folate deprivation, but red cell folate concentrations remain stable for longer, as they more accurately reflect tissue stores of folate. Prolonged folate deficiency leads to megaloblastic anemia, which can result in increased levels of serum homocysteine concentrations in adults and neural tube defects in the fetus. Measurements of both serum and red cell concentrations of folate provide the best assessment of folate status (also see the following section, "Vitamin $\mathrm{B}_{12}$ "). In general, the microbiological method is used to quantify both red cell and serum folate concentrations; other possible methods are mass spectrometry and protein-binding assays. Normal concentrations are $\geq 10 \mathrm{nmol} / \mathrm{L}$ for serum folate and $\geq 340 \mathrm{nmol} / \mathrm{L}$ for RBC folate. ${ }^{8}$

\section{Vitamin $B_{12}$ (cyanocobalamin)}

Vitamin $\mathrm{B}_{12}$ is only present in animal-source foods, so deficiency is prevalent when the intake of these foods is low because of high cost, lack of availability, cultural or religious beliefs, ${ }^{8}$ or malabsorption due to lack of intrinsic factor in gastric parietal cells of the stomach (this final example is called pernicious anemia, a megaloblastic anemia). The metabolism of folate and $\mathrm{B}_{12}$ are linked, in that vitamin $\mathrm{B}_{12}$ is needed for the metabolism of folate, and in the absence of vitamin $\mathrm{B}_{12}$, folate is trapped as N5-methyltetrahydrofolate and cannot be recycled back to the folate pool. A low RBC folate can therefore indicate primary vitamin $B_{12}$ deficiency. Inadequate intake of vitamin $B_{12}$ leads to low plasma concentrations, an elevated plasma homocysteine concentration, and elevated urinary or serum methylmalonic acid concentrations. A deficiency of vitamin $B_{12}$ is also associated with megaloblastic anemia as well as neurological symptoms caused by defects in myelin synthesis. Normal plasma concentrations for vitamin $B_{12}$ are $\geq 150 \mathrm{pmol} / \mathrm{L}$, measured by a microbiological assay. ${ }^{8}$

\section{Vitamin A}

Vitamin A status is widely reported to influence iron metabolism but the precise mechanism is not yet elucidated..$^{33}$ Vitamin A deficiency (VAD) and anemia often coexist in populations, and supplementation studies suggest that there is an additive reduction in iron-deficiency anemia following a combined supplement of vitamin A and iron in comparison with the effects of the nutrients given alone. ${ }^{34}$ However, inflammation depresses both plasma retinol concentrations and the mobilization of iron, ${ }^{14}$ so the role of infection in the vitamin A-iron interaction should not be overlooked. Biochemically, a risk of VAD is defined as a serum retinol concentration $<0.7 \mu \mathrm{mol} / \mathrm{L} .{ }^{35} \mathrm{WHO}$ estimates suggest that VAD is a global problem in preschool-age children (190 million; 95\% CI: 178, 202) and pregnant women (19.1 million; $95 \%$ CI: $9.3,29$ ), equivalent to $33.3 \%$ and $15.3 \%$ of the global population, respectively. ${ }^{35}$ Vitamin $\mathrm{A}$ is found in two forms in the diet: (1) as provitamin carotenoids, such as beta-carotene, in vegetables and fruits and (2) as retinol in animal products. Retinol or retinol esters from animal-source foods are more bioavailable than provitamin carotenoids but are relatively expensive; vegetables, on the other hand, are widely available and inexpensive but are undervalued and underutilized. 


\section{Vitamin $\mathrm{B}_{2}$ (riboflavin [7,8-dimethyl- |0-ribityl-} isoalloxazine; vitamin $\left.B_{2}\right]$ )

Riboflavin-responsive anemia was first described by Foy and Kondi ${ }^{4,5}$ about 60 years ago. This anemia is characterized by erythroid hypoplasia (small number of red cells produced) and reticulocytopenia (abnormal decrease in reticulocytes). Riboflavin deficiency alters iron metabolism and, although the mechanism is not clear, research in animals suggests that riboflavin deficiency may impair iron absorption, increase intestinal loss of iron, and/or impair iron utilization for the synthesis of Hb. ${ }^{36}$ Riboflavin is a water-soluble vitamin present especially in dairy products but it is also found in lesser amounts in other foods. Riboflavin functions in the body as an integral part of two coenzymes, flavin adenine dinucleotide and flavin mononucleotide, which take part in a range of oxidation-reduction reactions. ${ }^{36}$

In human studies, correction of riboflavin deficiency in pregnant and lactating women, adult males, and school-age children, all of whom were both riboflavin and iron deficient, improved the response of iron-deficiency anemia to iron therapy. ${ }^{37-39}$ In addition, studies using ${ }^{58} \mathrm{Fe}$ in adult Gambian men have suggested that improved riboflavin status increased mobilization of stored iron to raise $\mathrm{Hb}$ concentrations but that it had no measurable effect on iron absorption from the diet. ${ }^{40}$

\section{Vitamin $B_{6}$ (pyridoxine)}

Vitamin $\mathrm{B}_{6}$ occurs naturally in a variety of forms among foods of both plant and animal origin, but all are derivatives of 2-methyl-3-hydroxy-5-hydroxymethyl-pyridine. ${ }^{41}$ Vitamin $B_{6}$ is required as a coenzyme in the synthesis of delta-aminolevulinic acid, ${ }^{3}$ which is the first rate-limiting step in the synthesis of heme. Deficiency of vitamin $B_{6}$ is associated with microcytic hypochromic anemia but is rarely found.

\section{Hemoglobinopathies associated with anemia \\ $\mathrm{HbE}$}

In Southeast Asia, four main $\mathrm{Hb}$ variants have been identified linked with $\mathrm{Hb} \mathrm{E}$ and thalassemia, and all are major risk factors for anemia. The anemia observed is predominantly microcytic hypochromic anemia, which is the form commonly attributed to iron deficiency. In the normal adult $\mathrm{Hb}$, the globin molecule is made up of four polypeptide chains, two alpha and two beta, and is denoted by $\mathrm{HbAA}$. $\mathrm{Hb} \mathrm{E}$ disease arises from a genetic alteration in the physical structure of $\mathrm{Hb}$ - specifically, a single amino acid substitution in one of the beta-globin chains. The heterozygous form, denoted by $\mathrm{HbAE}$, is present when only one gene in the nucleus is affected; in the homozygous form, denoted by $\mathrm{HbEE}$, two genes are affected.

\section{Alpha-thalassemia}

In alpha-thalassemia ( $\alpha$-thalassemia), there is impaired synthesis of one or more of the $\alpha$-globin chains. When the deletion affects one $\alpha$-chain it is known as the $\alpha$-thalassemia trait, which can occur alone or be accompanied by HbAE. Both the latter forms tend to be asymptomatic and are known as thalassemia minor. $\mathrm{Hb}$ concentrations are lower in all variant $\mathrm{Hb}$ groups and sTfR and ferritin concentrations are all higher (Table 6). In Table 6 the ferritin concentrations indicated that most children had good iron status since mean ferritin concentrations were well above $12 \mathrm{ug} / \mathrm{L}$. This was in spite of downward adjustments to the ferritin values to compensate for the high prevalence of subclinical inflammation. ${ }^{13}$ Anemias due to $\mathrm{Hb} \mathrm{E}$ or $\alpha$-globin do not respond to iron therapy. ${ }^{42}$

\section{Sickle-cell disease}

Sickle-cell disease occurs mainly in African populations and is associated with the presence of sickle-cell $\mathrm{Hb}$, where one amino acid residue is different from that in normal adult $\mathrm{Hb}$. Sickle-cell disease results from the severe, genetically determined homozygous form, denoted by HbSS, where an abnormal gene is inherited from each parent. In contrast, the sickle-cell trait is the heterozygous form, denoted by $\mathrm{HbAS}$, where only one abnormal gene is inherited. In sickle-cell disease, the degree of anemia caused is variable but often severe and it is characteristically normochromic and normocytic. However, when in combination with iron, folate, or $\mathrm{B}_{12}$ deficiency, hypochromic or macrocytic megaloblastic anemias may be found. The reticulocyte count is usually raised $10 \%-20 \%$ and polychromasia is marked. In the sickle-cell trait, there is no anemia or evidence of increased red cell destruction and the reticulocyte count is normal. Only on exposure to anoxia do some of the erythrocytes take on the sickle-cell shape.

\section{Haptoglobin}

During intravascular hemolysis (eg, malaria and hemoglobinopathies), potentially tissue-damaging $\mathrm{Hb}$ is released into the plasma, where it is bound by the protective APP, haptoglobin (Hp). One molecule of Hp binds virtually irreversibly with two molecules of $\mathrm{Hb}^{43}$ to form a compound of higher molecular weight that cannot pass the renal glomeruli and which reduces the risk of iron loss and renal tubular injury. ${ }^{6,17}$ Serum Hp concentrations are a good indicator of 
hemolytic anemia, as normal $\mathrm{Hp}$ concentrations $(0.5-2.6 \mathrm{~g} / \mathrm{L})^{6}$ rapidly become undetectable if $\mathrm{Hb}$ is present, since the complex is rapidly cleared from the plasma by binding the $\mathrm{Hp}-\mathrm{Hb}$ complex to the specific receptor CD163 on circulating monocytes and macrophages and it is internalized..$^{44,45}$ The iron-loaded macrophages migrate to the reticuloendothelial system, where they can lodge for long periods until the inflammatory response subsides and the iron component can be recycled for erythropoiesis. ${ }^{45}$

Three phenotypes of Hp are found in humans: Hp1-1, Hp1-2, and Hp2-2. These phenotypes have been shown to bind $\mathrm{Hb}$ with different affinities: Hp1-1 > Hp1-2 > Hp2-2. $\mathrm{Hp} 2-2$ is the weakest $\mathrm{Hb}$ binder, and recent studies in the Gambia found that the fall in mean $\mathrm{Hb}$ concentration through the malaria season in children aged 2-6 years with the Hp2-2 phenotype was significantly greater by $4 \mathrm{~g} / \mathrm{L}$ than in those with the other phenotypes. ${ }^{46}$ The Hp2-2 phenotype is associated with higher levels of oxidant stress, which may confer antimalarial benefits at the expense of $\mathrm{Hb}$ loss. Thus, while the Hp2-2 phenotype is a risk factor for anemia, its antimalarial properties made it comparable with glucose-6phosphate dehydrogenase (G6PD) deficiency and HbAS in malaria-endemic areas. The $\mathrm{Hp}-\mathrm{Hb}$ phenotype may protect against life-threatening malaria at the expense of impaired hematological recovery from mild asymptomatic malaria. ${ }^{46}$

\section{G6PD}

Because G6PD deficiency is inherited as a sex-linked character and is carried on the $\mathrm{X}$ chromosome, deficient variants are expressed more commonly in males than in females. Worldwide, an estimated 400 million people are G6PD deficient, with the distribution corresponding to areas in which malaria is or has been prevalent; it is most common in West Africa, Central Africa, the Mediterranean region, the Middle East, and Southeast Asia. ${ }^{47}$ There is some evidence that hemizygous males may be protected against severe malaria.

G6PD deficiency is characterized by abnormally low levels of G6PD, an enzyme in the pentose phosphate pathway of $\mathrm{RBCs}$, which is the only biochemical pathway for generating energy in the form of NADPH and reduced glutathione. ${ }^{47}$ The G6PD gene is highly polymorphic, with almost 400 reported variants, but in sub-Saharan Africa there are three main variants: G6PD-B (wild type, full enzyme activity) and two mutations, G6PD-A+ and G6PD-A-. G6PD-A+ retains $90 \%$ of full activity but G6PD-A- retains only $8 \%-20 \%$ of the wild-type enzyme activity. Individuals with G6PD-A- are normally asymptomatic; however, erythrocyte exposure to oxidative stress such as infections and certain foods ${ }^{48}$ and drugs, including antimalarial treatments, cause $\mathrm{Hb}$ denaturation, ultimately resulting in hemolytic anemia.

\section{Inflammation and anemia}

\section{Serum ferritin and the acute-phase response}

In 2004, the WHO working group recognized ferritin as probably the most useful biomarker of iron status, ${ }^{7}$ but, because it is also a positive APP, the group recommended that ferritin measurements should be accompanied by the analysis of one or more APPs to detect the presence of subclinical infection or inflammation.

At the onset of an infection, serum ferritin concentrations rise rapidly and in parallel with CRP concentrations. ${ }^{49}$ During the clinical infection, ferritin concentrations remain high, ${ }^{50}$ but they do not fall when CRP concentrations fall as clinical signs disappear. ${ }^{49}$ Instead, ferritin concentration can remain high into the convalescent period, similar to the behavior of the "chronic" APP biomarker, AGP. ${ }^{13,22}$ For the physician handling diseased patients, a high ferritin concentration associated with anemia is of little surprise and his or her main objective is to cure the patient to reestablish normal hematopoiesis. However, although patients in convalescence may be apparently healthy and no longer in clinical care, to interpret their ferritin concentrations correctly it is important to establish whether there is any evidence of residual subclinical inflammation.

\section{Correcting serum ferritin concentrations for inflammation}

Correcting ferritin for subclinical inflammation can be done using the methods described by Thurnham et al. ${ }^{13}$ At the onset of an infection, CRP concentrations rise rapidly over the first 24-48 hours before clinical evidence of disease appears (the incubation period). In contrast, AGP rises much more slowly and it only reaches a maximum after 4-5 days. When the clinical phase of the disease subsides, CRP falls but AGP remains elevated. In a meta-analysis, using these inflammation proteins the present authors allocated subjects to three inflammatory groups: (1) incubation (only CRP is raised), (2) early convalescence (both CRP and AGP are raised), and (3) late convalescence (only AGP is raised). The authors defined inflammation using cutoff values $>5 \mathrm{mg} / \mathrm{L}$ for CRP and $>1 \mathrm{~g} / \mathrm{L}$ for AGP. Subjects with no raised APP formed the reference group. Correction factors were calculated from the ratios of the geometric means of the inflammatory/reference groups and, from a meta-analysis of 22 studies, correction factors for the incubation, early convalescent, and late convalescent groups were $0.77,0.53$, and 0.75 , respectively. ${ }^{13}$ Ferritin concentrations are corrected by multiplying the ferritin concentration of 
subjects in the three inflammatory groups by their respective correction factors. Using this technique, the authors ${ }^{13}$ and others $^{51}$ showed that removing the effects of inflammation increased the prevalence of iron deficiency.

\section{Clinical usefulness of biomarkers}

In the preceding sections, the authors have described the main biomarkers that are associated with anemia. Use of these biomarkers will help identify the factors that potentially may have caused anemia in patients and groups of subjects in the community. It has to be remembered, however, that anemia is the final stage of a set of circumstances involving dietary deficiencies, parasites such as malaria or hookworm, or metabolic factors such as hemoglobinopathies and so forth. Dietary deficiencies of iron, folate, vitamin $\mathrm{B}_{12}$, pyridoxine, or riboflavin can limit the synthesis of $\mathrm{Hb}$ or $\mathrm{RBCs},{ }^{41}$ or erythrocytes can be destroyed so rapidly that the body is unable to carry out red cell replenishment quickly enough - as, for example, in malaria ${ }^{52}$ or in an oxidative crisis in people with congenital G6PD deficiency. ${ }^{48}$ Furthermore, when there is no overt cause of a severe anemia, examining potential biomarkers in patients may not be particularly helpful in establishing the etiology of the anemia. In a case-control study in rural Malawi of 381 children under the age of 2 years with severe anemia $(\mathrm{Hb}<50 \mathrm{~g} / \mathrm{L})$ and 757 similar children without severe anemia, there were seven factors that contributed significantly to explaining the severe anemia: (1) bacteremia, (2) malaria, (3) hookworm, (4) human immunodeficiency virus, (5) G6PD deficiency, (6) vitamin A deficiency, and (7) vitamin $B_{12}$ deficiency. ${ }^{53}$ No one factor explained more than $5.3 \%$ of the severe anemia. The authors concluded that there were multiple causes of severe anemia but folate and iron deficiencies were not prominent among them. Additionally, the authors cautioned that even in the presence of malaria parasites, additional or alternative causes of severe malaria should be considered.

It is noteworthy that four of the seven factors contributing to the severe anemia in the Malawian infants were infections. There is a common feature of infections - namely, that they activate the acute-phase response. ${ }^{10}$ An acute-phase response will restrict the supply of iron to the bone marrow, as previously described, ${ }^{23,54}$ and reduce concentrations of several other nutrients involved directly and indirectly in red cell synthesis, including plasma retinol ${ }^{55}$ and vitamin $\mathrm{B}_{6}{ }^{56}$ Low concentrations of plasma retinol have been associated with increased morbidity, so one infection may increase susceptibility to another, especially when disease is highly endemic, as it is in much of the developing world. ${ }^{10,24}$ Studies in the
Gambia support this suggestion, and the present authors observed an increasing prevalence of both acute and chronic inflammation in Gambian infants through the first 12 months of life, with anemia $(\mathrm{Hb}<90 \mathrm{~g} / \mathrm{L})$ increasing in parallel from $20 \%$ at 3 months of age to $48 \%, 62 \%$, and $67 \%$ at 6,9 , and 12 months of age, respectively. ${ }^{57,58}$ The increase in prevalence of moderate anemia was not linked to seasonal factors, since infants were recruited over 3 years and the effects spanned both wet and dry seasons and seasonal diseases. Instead, the authors believe the increase in moderate anemia is at least partially the result of increasing exposure to pathogens with age and the inability to completely overcome the effects of one infection before exposure to the next.

Iron supplementation has been considered standard treatment for anemia over many years in both the developed and the developing worlds but it has often not been very effective. The reasons given have included lack of bioavailability, insufficient dose, side effects, and compliance. ${ }^{59,60}$ However, it is now increasingly recognized that other factors may be equally as or more important than iron deficiency in the etiology of anemia. Infectious diseases, contaminated water, and poor hygiene are widespread in the developing world and prevalence rates for anemia are also high. In contrast, in the developed world, prevalence rates for anemia are much lower and infectious diseases have been largely controlled by vaccinations, clean water supplies, access to medical care, and improved hygiene. Improvements in public health in developing countries are taking place slowly, ${ }^{61}$ but poverty and limited opportunities to break the disease-malnutrition cycle will prevent any great reductions in anemia prevalence in many developing countries for the foreseeable future.

\section{Conclusion}

Anemia is of multifactorial etiology, but it is to be hoped that by using the biomarkers described in this review, investigators will obtain a fuller understanding of the potential causes of anemia. Automated cell counters provide much useful information to point to potential causes of anemia, but no one method will ever be sufficient to describe the full etiology of anemia. Specific tests may confirm the underlying causes but anemia is the result of a complex interaction of events, which may be difficult to unravel. This review lists the biomarkers that can be used to determine the most likely causes of anemia, but the authors emphasize that anemia is the final stage in a deterioration in red cell synthesis to a point when anemia is defined. At that stage the factors associated with anemia may not fully reflect the circumstances that were 
responsible for the initial or the progress of deterioration in red cell synthesis.

\section{Disclosure}

The authors report no conflicts of interest in this work.

\section{References}

1. De Benoist B, McLean E, Egli I, Cogswell ME, editors; World Health Organization (WHO). Worldwide Prevalence of Anaemia 1993-2005. WHO Global Database on Anaemia. Geneva, Switzerland: WHO; 2008.

2. United Nations Children's Fund, United Nations University, World Health Organization (WHO). Iron Deficiency Anaemia: Assessment, Prevention and Control; A Guide for Programme Managers. WHO/ NHD/01.3. Geneva, Switzerland: WHO; 2001.

3. Clayton PT. B6-responsive disorders: a model of vitamin dependency. J Inherit Metab Dis. 2006;29(2-3):317-326.

4. Foy H, Kondi A. A case of true red-cell aplastic anaemia successfully treated with riboflavin. J Pathol Bacteriol. 1953;65(2):559-564.

5. Foy H, Kondi A. Anaemias of the tropics: East Africa, with special reference to proteins and liver damage. Trans $R$ Soc Trop Med Hyg. 1958;52(1):46-70.

6. Thompson RB. A Short Textbook of Haematology. 4th ed. Tunbridge Wells, Kent: Pitman Medical Publishing Company; 1975.

7. World Health Organization (WHO), Centers for Disease Control and Prevention. Assessing the Iron Status of Populations, 2nd ed. Geneva, Switzerland: WHO; 2007.

8. De Benoist B. Conclusions of a WHO technical consultation on folate and vitamin B12 deficiencies. Food Nutr Bull. 2008;29(Suppl 2): S238-S244.

9. United Nations Administrative Committee on Coordination/SubCommittee on Nutrition (ACC/SCN). Third Report on the World Nutrition Situation. Geneva, Switzerland: ACC/SCN; 1997.

10. Thurnham DI, Northrop-Clewes CA. Infection in the etiology of anemia. In: Kraemer K, Zimmermann MB, editors. Nutritional Anemia. Basel, Switzerland: Sight and Life Press; 2007:231-256.

11. Adenbrooke's Hospital. Biochemistry Test Information: Version 2.71. Cambridge: Adenbrooke's Hospital; 2010. Available from: http:// baspath.co.uk/clinical_chemistry/guidelines/Addenbrookes\%20 Immunology\%20Handbook\%20v2.71.pdf. Accessed September 25, 2012.

12. Bessman JD, Gilmer PR Jr, Gardner FH. Improved classification of anemias by MCV and RDW. Am J Clin Pathol. 1983;80(3): 322-326.

13. Thurnham DI, McCabe LD, Haldar S, Wieringa FT, NorthropClewes CA, McCabe GP. Adjusting plasma ferritin concentrations to remove the effects of subclinical inflammation in the assessment of iron deficiency: a meta-analysis. Am J Clin Nutr. 2010;92(3):546-555.

14. Thurnham DI, McCabe GP. Influence of infection and inflammation on biomarkers of nutritional status with an emphasis on vitamin A and iron. In: World Health Organization (WHO). Report: Priorities in the Assessment of Vitamin A and Iron Status in Populations; Panama City, Panama; 15-17 September 2010. Geneva, Switzerland: WHO; 2012:63-80.

15. Dale JC, Burritt MF, Zinsmeister AR. Diurnal variation of serum iron, iron-binding capacity, transferrin saturation, and ferritin levels. $\mathrm{Am} \mathrm{J}$ Clin Pathol. 2002;117(5):802-808.

16. Beisel WR. Trace element in infectious processes. Med Clin North Am. 1976;60(4):831-849.

17. Bothwell TH, Charlton RW, Cook JD, Finch CA. Iron Metabolism in Man. Oxford: Blackwell Scientific Publications; 1979.

18. Flo TH, Smith KD, Sato S, et al. Lipocalin 2 mediates an innate immune response to bacterial infection by sequestrating iron. Nature. 2004;432(7019):917-921.
19. Cook JD, Flowers CH, Skikne BS. The quantitative assessment of body iron. Blood. 2003;101(9):3359-3364.

20. Skikne BS, Flowers CH, Cook JD. Serum transferrin receptor: a quantitative measure of tissue iron deficiency. Blood. 1990;75(9): $1870-1876$.

21. Beard JL. Iron biology in immune function, muscle metabolism and neuronal functioning. J Nutr. 2001;131(2 Suppl 2):S568-S579.

22. Northrop-Clewes CA. Interpreting indicators of iron status during an acute phase response: lessons from malaria and human immunodeficiency virus. Ann Clin Biochem. 2008;45(Pt 1):18-32.

23. Collins JF, Wessling-Resnick M, Knutson MD. Hepcidin regulation of iron transport. J Nutr. 2008;138(11):2284-2288.

24. Thurnham DI. Vitamin A, iron, and haematopoiesis. Lancet. 1993;342(8883):1312-1313.

25. Thorpe SJ, Heath A, Sharp G, Cook J, Ellis R, Worwood M. A WHO reference reagent for the Serum Transferrin Receptor (sTfR): international collaborative study to evaluate a recombinant soluble transferrin receptor preparation. Clin Chem Lab Med. 2010;48(6):815-820.

26. Erhardt JG, Estes JE, Pfeiffer CM, Biesalski HK, Craft NE. Combined measurement of ferritin, soluble transferrin receptor, retinol binding protein, and C-reactive protein by an inexpensive, sensitive, and simple sandwich enzyme-linked immunosorbent assay technique. $J$ Nutr. 2004;134(11):3127-3132.

27. Allen J, Blackstrom KR, Cooper JA, et al. Measurement of soluble transferrin receptor in serum of healthy adults. Clin Chem. 1998;44(1): $35-39$.

28. Virtanen MA, Viinikka LU, Virtanen MK, et al. Higher concentrations of serum transferrin receptor in children than in adults. Am J Clin Nutr. 1999;69(2):256-260.

29. Beguin Y. Soluble transferrin receptor for the evaluation of erythropoiesis and iron status. Clin Chim Acta. 2003;329(1-2):9-22.

30. Spivak JL. The blood in systemic disorders. Lancet. 2000;355(9216): 1707-1712.

31. Nielsen OJ, Andersen LS, Hansen NE, Hansen TM. Serum transferrin receptor levels in anaemic patients with rheumatoid arthritis. Scand J Clin Lab Invest. 1994;54(1):75-82.

32. Beguin Y, Clemons GK, Pootrakul P, Fillet G. Quantitative assessment of erythropoiesis and functional classification of anemia based on measurements of serum transferrin receptor and erythropoietin. Blood. 1993;81(4):1067-1076.

33. Semba RD, Bloem MW. The anemia of vitamin A deficiency: epidemiology and pathogenesis. Eur J Clin Nutr. 2002;56(4):271-281.

34. Suharno D, West CE, Muhilal, Karyadi D, Hautvast JG. Supplementation with vitamin A and iron for nutritional anaemia in pregnant women in West Java, Indonesia. Lancet. 1993;342(8883): 1325-1328.

35. World Health Organization (WHO). Global Prevalence of Vitamin A Deficiency in Populations at Risk 1995-2005: WHO Global Database on Vitamin A Deficiency. Geneva, Switzerland: WHO; 2009.

36. Powers HJ. Riboflavin (vitamin B-2) and health. Am J Clin Nutr. 2003;77(6): 1352-1360.

37. Powers HJ, Bates CJ, Duerden JM. Effects of riboflavin deficiency in rats on some aspects of iron metabolism. Int $J$ Vitam Nutr Res. 1983;53(4):371-376.

38. Decker K, Dotis B, Glatzle D, Hinselmann M. Riboflavin status and anaemia in pregnant women. Nutr Metab. 1977;21 Suppl 1:17-19.

39. Buzina R, Jusić M, Milanović N, Sapurnar J, Brubacher G. The effects of riboflavin administration on iron metabolism parameters in a schoolgoing population. Int J Vitam Nutr Res. 1979;49(2):136-143.

40. Fairweather-Tait SJ, Powers HJ, Minski MJ, Whitehead J, Downes R. Riboflavin deficiency and iron absorption in adult Gambian men. Ann Nutr Metab. 1992;36(1):34-40.

41. Pallister C. Nutritional requirements for haemopoiesis. In: Pallister C. Blood: Physiology and Pathophysiology. Oxford: Butterworth-Heinemann; 1994:33-52.

42. George J, Yiannakis M, Main B, et al. Genetic hemoglobin disorders, infection, and deficiencies of iron and vitamin A determine anemia in young Cambodian children. J Nutr. 2012;142(4):781-787. 
43. Andersen CB, Torvund-Jensen M, Nielsen MJ, et al. Structure of the haptoglobin-haemoglobin complex. Nature. 2012;489(7416): 456-459.

44. Gupta S, Ahern K, Nakhl F, Forte F. Clinical usefulness of haptoglobin levels to evaluate hemolysis in recently transfused patients. $A d v$ Hematol. 2011;2011:389854.

45. Cox SE, Doherty C, Atkinson SH, et al. Haplotype association between haptoglobin (Hp2) and $\mathrm{Hp}$ promoter SNP (A-61C) may explain previous controversy of haptoglobin and malaria protection. PLoS One. 2007; 2(4):e362.

46. Atkinson SH, Rockett K, Sirugo G, et al. Seasonal childhood anaemia in West Africa is associated with the haptoglobin 2-2 genotype. PLoS Med. 2006;3(5):e172.

47. Carter N, Pamba A, Duparc S, Waitumbi JN. Frequency of glucose6-phosphate dehydrogenase deficiency in malaria patients from six African countries enrolled in two randomized anti-malarial clinical trials. Malar J. 2011;10:241.

48. Mehta JB, Singhal SB, Mehta BC. Ascorbic-acid-induced haemolysis in G-6-PD deficiency. Lancet. 1990;336(8720):944.

49. Feelders RA, Vreugdenhil G, Eggermont AM, Kuiper-Kramer PA, van Eijk HG, Swaak AJ. Regulation of iron metabolism in the acutephase response: interferon gamma and tumor necrosis factor alpha induce hypoferraemia, ferritin production and a decrease in circulating transferrin receptors in cancer patients. Eur J Clin Invest. 1998;28(7): 520-527.

50. Phiri KS, Calis JC, Siyasiya A, Bates I, Brabin B, Boele van Hensbroek MB. New cut-off values for ferritin and soluble transferrin receptor for the assessment of iron deficiency in children in a high infection pressure area. J Clin Pathol. 2009;62(12):1103-1106.

51. Grant FK, Suchdev PS, Flores-Ayala R, et al. Correcting for inflammation changes estimates of iron deficiency among rural Kenyan preschool children. J Nutr. 2012;142(1):105-111.

52. Bojang KA, Palmer A, Boele van Hensbroek M, Banya WA, Greenwood BM. Management of severe malarial anaemia in Gambian children. Trans R Soc Trop Med Hyg. 1979;91(5):557-561.
53. Calis JC, Phiri KS, Faragher EB, et al. Severe anemia in Malawian children. N Engl J Med. 2008;358(9):888-899.

54. Prentice AM, Cox SE, Nweneka CV. Asymptomatic malaria in the etiology of iron deficiency anemia: a nutritionist's viewpoint. Am J Clin Nutr. 2010;92(6):1283-1284.

55. Thurnham DI, McCabe GP, Northrop-Clewes CA, Nestel P. Effects of subclinical infection on plasma retinol concentrations and assessment of prevalence of vitamin A deficiency: meta-analysis. Lancet. 2003;362(9401):2052-2058.

56. Bates CJ, Pentieva KD, Prentice A, Mansoor MA, Finch S. Plasma pyridoxal phosphate and pyridoxic acid and their relationship to plasma homocysteine in a representative sample of British men and women aged 65 years and over. Br J Nutr. 1999;81(3):191-201.

57. Darboe MK, Thurnham DI, Morgan G, et al. Effectiveness of an early supplementation scheme of high-dose vitamin A versus standard WHO protocol in Gambian mothers and infants: a randomised controlled trial. Lancet. 2007;369(9579):2088-2096.

58. Thurnham DI. Monitoring anemia-control programs. Sight and Life. 2009;1:59-66.

59. Gibson RS, Bailey KB, Gibbs M, et al. A review of phytate, iron, zinc, and calcium concentrations in plant-based complementary foods used in low-income countries and implications for bioavailability. Food Nutr Bull. 2010;31:S134-S146.

60. Schultink W, van der Ree M, Matulesi P, et al. Low compliance with an iron-supplementation program: a study among pregnant women in Jakarta, Indonesia. Am J Clin Nutr. 1993;57(2):135-139.

61. Laillou A, Pham TV, Tran NT, et al. Micronutrient deficits are still public health issues among women and young children in Vietnam. PLoS One. 2012;7(4):e34906.

62. Adamson JW, Longo DL. Anemia and polycythemia. In: Braunwald E, Fauci AS, Kasper DL, Hauser SL, Longo DL, Jameson JL, editors. Harrison's Principles of Internal Medicine, 15th ed. New York: McGraw Hill; 2001.
Journal of Blood Medicine

\section{Publish your work in this journal}

The Journal of Blood Medicine is an international, peer-reviewed, open access, online journal publishing laboratory, experimental and clinical aspects of all topics pertaining to blood based medicine including but not limited to: Transfusion Medicine; Blood collection, Donor issues, Transmittable diseases, and Blood banking logistics; Immunohematology; Artificial and alternative

\section{Dovepress}

blood based therapeutics; Hematology; Biotechnology/nanotechnology of blood related medicine; Legal aspects of blood medicine; Historical perspectives. The manuscript management system is completely online and includes a very quick and fair peer-review system. Visit http://www.dovepress.com/ testimonials.php to read real quotes from published authors. 